\title{
Situations analysis of the malt barley value chain integration and performance in
}

\section{Ethiopia}

Mulugeta D. Watabaji ${ }^{1,2 *}$, Adrienn Molnár ${ }^{1,3}$, Xavier Gellynck ${ }^{1}$

${ }^{1}$ Ghent University, Department of Agricultural Economics, Coupure links 653, 9000 Ghent, Belgium

${ }^{2}$ Haramaya University, Department of Agribusiness Management, P.O.Box 138, Dire Dawa, Ethiopia

${ }^{3}$ Hungarian Academy of Sciences, Institute of Economics, Research Centre for Economics and Regional Studies, Budaörsi út 45, 1112 Budapest, Hungary

*Corresponding author: mulied75@yahoo.com

\begin{abstract}
This study explores the malt barley value chain in Ethiopia with emphasis on value chain structure, integration and performance and their interactions. Data were gathered from individual chain members through qualitative interviews and analyzed according to definitions of concepts in the literature and their arrangements in our conceptual framework. We identified several fragmentations in the studied value chain structure which constrained chain's performance by weakening its integration. The major causes of the fragmentation were lack of value chain-thinking, opportunistic traders, weak cooperative organizations, poor information sharing, and less support from the malt factory and breweries to the upstream members of the chain. The conceptual framework was presented to guide future analysis, open managerial and policy dialogues and initiate questions for future research to identify new ways of linking small-scale farmers to large agro-processors in the Sub-Sahara Africa.
\end{abstract}

Keywords: geographic dispersion, vertical/horizontal arrangement, information flows, transaction governance collaboration, commitment, coordination, joint decision making

\section{Introduction}

Value chain structure (VCS) refers to geographic dispersion of value chain members, their horizontal and vertical arrangements (Lambert and Cooper, 2000), the information flows (Wu Et al., 2004; Mungandi Et al., 2012) and transactions governance in the value chains (Stock Et al., 2000). Members' geographic dispersion alludes to the distribution of members over a given area. Transaction governance refers to the control exercised by value chain members 
over other members during exchange transactions which ranges from a spot-market (with less control) to a hierarchy (with more control) and, hybrid governance with moderate control level in between the extremes (Gellynck and Molnár, 2009). Though the components of VCS are believed to influence that of value chain integration (VCI), it was not sufficiently studied yet (Slone Et al., 2007; Stock Et al., 2000).

Value chain integration has become a prominent research area (Wu Et al., 2004) due to its importance in the conceptualization of the discipline of value chain management (Romano, 2003). It refers to the spirit of collaboration among members (Cao and Zhang, 2010) and coordination of activities and decisions (Villena Et al., 2009) to accomplish common goals. The first step towards VCI, from a focal company point of view, is to work with immediate suppliers and customers closely. Once these are integrated with the focal member, it is easier for this member to work with its suppliers' suppliers and customers' customers (Lambert and Cooper, 2000).

Value chain members have already recognized the importance of VCI to enhance value chain performance (VCP) and put consistent efforts towards it to achieve high performance outcomes (Stock Et al., 2000). However failure to put consistent efforts towards VCI affects not only the performance individual members, but also that of other members (Gellynck Et al., 2008; Lambert and Cooper, 2000) and hardly achieves competitive advantage (Dolan and Humphrey, 2000). Consequently, the impact of VCI on VCP is often hypothesized; previous empirical research shows that VCI is a cornerstone of VCP (Pagell, 2004; Villena Et al., 2009). In the view of Awad and Nassar (2010), for instance high VCP leads to strong VCI, while Ho Et al. (2002) doubt the existence of positive relationship between VCI and VCP. As such, the relationship between VCI and VCP was not satisfactorily studied empirically which provides the knowledge gap for this study to fill.

Based on the identified literature gaps and the needs to better integrate small-scale farmers to large agro-processors in the malt value chain (MBVC) in Ethiopia, the specific objectives of this study are to (i) explore VCS, VCI and VCP, (ii) analyze how components of VCS influence VCP through VCI, and (iii) formulate key propositions for further investigation. The study contributes to the conceptualization of the interactions among VCS, VCI and VCP and also towards the facilitation of commercialization processes of Ethiopian agriculture which was the main objective the NICHE ETH019 project. 


\section{Conceptual framework}

In the past, the term "structure" was commonly used in organizational management literature to show the division of tasks, authorities and responsibilities or to express the unity of order or command within a single company (Pagell, 2004; Stock Et al., 2000). The use of the word in value chain context VCS is a recent phenomenon and refers to the geographic dispersion of members' location, their horizontal and vertical arrangements, information flows, and the transaction governance (Stock Et al., 2000). On the other hand, VCI is considered as a new approach to overcome individual member's failure in the overall value chain context (Bitzer, 2012). It involves concepts of collaboration among members, coordination of activities across the value chain, members' commitments towards common goals and joint decisions (Kwon and Suh, 2004; Min Et al., 2005). Past studies have employed different approaches to measure VCP (Stock Et al., 2000). Mostly, product quality, responsiveness, flexibility and efficiency have been used to measure VCP (Molnar, 2010). According to past studies, product quality refers to the purity of the product; flexibility indicates members' capabilities to respond to changes; responsiveness measures members' ability to deliver products to satisfy needs of customers within the shortest possible lead-time; and efficiency deals with the maximization of profit by keeping the costs of inputs as low as possible without compromising quality.

In their study of enterprise logistics and chain structure, Stock Et al. (2000) formulated a conceptual framework that fits VCS to VCI to improve VCP. Pagell (2004) used similar concepts to study factors that influence internal integration of functional units of a single firm. In her study on chain performance and relationships in the European traditional food sector, Molnar (2010) formulated a similar conceptual framework, but there was an overlap of concepts of VCS and VCI. Similarly, Ghosh and Fedorowicz (2008) formulated a conceptual framework that links value chain governance, integration and performance and that partially replicates the sequential relationships along VCS-VCI-VCP constructs. Based on these studies and intensive reviews of literature, a conceptual framework for this study was formulated, see Figure 1.

\section{Research methodology}

As suggested by Baxter and Jack (2008), a holistic qualitative case study approach was employed for this study. Maximum care was taken not to deny some of members the attention they deserve while more attention is given to other members, which is a common mistake in 
most case studies. This study was limited to MBVC in Ethiopia. We selected key informants for interviews from four purposively-selected districts in Arsi and West Arsi zones of Oromia state. The districts were selected based on area coverage and volume of surplus malt barley produced based on information obtained from the Assela malt factory (AMF). Tiyyo and Lemu-Bilbilo districts were taken from Arsi zone and Kofele and Shashemene districts from West Arsi Zone. The AMF and four breweries namely: Saint George, a full subsidiary of Society for Brassiere and Glaciers International Plc. (BGI); Meta, a full subsidiary of Diageo Plc and, Bedele and Harar both full subsidiaries of the Heineken NV were also included in the sample, see Figure 2.

Primary data were collected mainly through qualitative interviews. Interview guides were prepared in advance to enhance data consistency and reliability. This approach helped us obtain more inclusive and conclusive information (Bastl Et al., 2012). During interviews, respondents were asked to explain what they know about the structure, integration and performance of the MBVC. More specifically, they were asked to identify members that participate in the MBVC, the roles of each members, their arrangement within and along chain tiers, the smoothness of information flows, the level of information quality, transaction governance, the strength of MBVC integration, the method of VCP measurement and the level of satisfaction with the currently obtained VCP outcomes and the like..

\section{Sampling and data analysis}

A multistage sampling technique was employed to select districts and key informants from among members operating at various stages of the MBVC (Bastl Et al., 2012). In total, 76 interviews were conducted of which 27 were with farmers; 13 with traders; 17 with cooperative staff, 5 with managers of AMF, 11 with managers of breweries, 2 with managers of the Ethiopian Seed Enterprise (ESE) and 1 was with the coordinator of the MBVC improvement project funded by the Self Help International, a non-governmental organization. The identities of the key informants were kept confidential. The interviews were conducted during June to August 2013 either in Afan Oromo or Amharic languages based on respondents' preferences. All interviews were recorded, transcribed and synthesized. The durations of interviews ranged from 45 minutes to 2 hours. A deductive research approach whereby existing theories on value chain structure, integration and performance was employed to explore the same issues in the MBVC to come up with key researchable propositions. Though solicited from individual MBVC members, interview responses were put into a chain context during the analysis (Vieira and Traill, 2008). Thus, all responses were 
analyzed within the context of the MBVC to obtain clear picture about the structure, integration and performance of the chain. The interview responses were initially transcribed and then organized, and finally analyzed based on definitions of concepts and perspectives as outlined in the conceptual framework (Vieira and Traill, 2008), hence template analysis was employed (Bastl Et al., 2012). Eventually, a complete set of logical links were established among VCS, VCI, and VCP and crucial propositions formulated from logical links (Ellram, 1996). Similar to the work of Mikkola (2008), with special attention given to contradicting views of members.

\section{Case description}

The MBVC encompasses millions of small-scale farmers, hundreds of traders and cooperatives, four breweries and a single malt factory as its key members. Though difficult to precisely describe small-scale farmers at the upstream tier of the chain, we adopted a definition provided by Brüntrup (1997). According to this scholar, these farmers are traditional peasants, resource poor, and users of less inputs and technologies. Though the agro-ecology of Ethiopia is highly suitable for malt barley production (Legesse Et al., 2007), farmers could not produce as much quantity and as good quality due to lack of or limited access to improved agricultural inputs, technologies, technical supports and or fair markets. The malt barley productivity and quality limitations accompanied by uncoordinated collection system strongly constrained the quantity and quality of local malt and breweries highly depend more on imported one. The demand for beer in Ethiopia is projected to grow at an estimated annual rate of $20 \%$ given the low per capita beer consumption of only 4 liters in contrast to that of neighboring Kenya whose per capita consumption of 12 liters. Population growth, increasing urbanization and raising personal incomes (Steen and Maijers, 2014) are major causes for the increasing consumption and demand of beer which in turn implicate the increase in demand for malt and malt barley. In order to meet the ever-increasing beer demand from local malt, breweries have already started to look for ways of strengthen MBVC integration to improve chain's performance.

\section{MBVC mapping}

Before proceeding with the investigation of detailed structure, integration and performance of MBVC, we mapped the key members to show the different flows (material, information, financial, information, technology) as depicted in Figure 2. For this study, data (both 
interview and survey) were collected from members (boxes shaded with parallel diagonal lines while members in boxes shaded with dots were neither interviewed nor surveyed.

\section{Malt barley and malt production}

The amount of malt barley produced by farmers and procured by the malt factory, farm size, and the malt produced by the malt factory fluctuate though the magnitude of the fluctuations are not so significant over the period of 2007-2013, see Table 1. Production figures in the four studied districts are far greater than purchase figures reported by AMF over the same period. This shows the sufficiency of the malt barley produced in the study area to meet the total requirement of AMF if properly collected. However, a large part of malt barley is either consumed by farmers or goes through other competing channels (e.g. urban consumers or flour factories). As such, AMF's demand is often not met. It was observed that the volume of malt barley procured and malt produced by AMF change along with the land-size of used for the production of same crop and the volume of production.

\section{Results and discussion}

\section{The MBVC structure}

The recent entrance of multinational breweries such as Society for Brassiere and Glaciers International (BGI), Heineken NV, and Diageo Plc to the Ethiopian beer sector is a meteoric opportunity for the chain to develop on top of the recent rapid growth in the local beer market. However, there are several challenges related to chain's structure that the new entrants should tackle together with other members. These multinationals are currently working towards meeting high targets of local malt sourcing. For instance, Heineken NV aspires to meet $60 \%$ of its malt requirement from local source by 2020 and has started to make some interventions at grassroots level to meet this target. Other breweries have similar targets in relation to local sourcing.

In MBVC, millions of small-scale farmers produce less quantity and poor quality malt barley due to small land size, lack of proper inputs, use of traditional farming practices, and lack of specialization. Though cooperatives are known for effectively linking framers to big agroprocessing companies (Bijman Et al., 2010), those in study area are poorly organized and weak. They could not support the farmers on materials/information flows and technology dissemination (Vandeplas Et al., 2013). Moreover, they could not establish uniformity in malt barley quality by coordinating the activities of dispersedly located farmers. Similarly, Stock Et al. (2000) expressed that geographic dispersion of members' location causes weak 
integration. According to our own field survey, farmers need to travel for 5:25 hours, on average, by car to reach the AMF due to long distance and poor transport facilities. Moreover, a farmer should be able to supply a minimum of 5 tons of malt barley per transaction if she/he opts for direct sales to the malt factory. Many farmers do not have the capacity to meet the minimum required supply per transaction and it is also difficult for them to supply in groups due to quality variations. Farmers have literally no option than to sell to traders at very low prices. In a similar vein, breweries are dispersedly located though one can still argue whether a disperse location of members weakens VCI. Hence, the following proposition needs further investigation.

Proposition 1: The more disperse the geographic locations of value chain members, the weaker the chain's integration.

In this study, like the study by Lambert and Cooper (2000), horizontal VCS refers to the number of triers that form the MBVC. It is what determines the length of the chain. Though farmers repeatedly implored the malt factory to establish collection centres in nearby towns to support direct sales, the economic feasibility of these centres has been doubtful to the factory. As indicated earlier, cooperatives are expected to play a key role in bridging farmers and AMF. Cooperatives failure to do so gave a space in the chain to opportunistic traders who reap higher benefits while adding no or little value. In the view of AMF managers, it is not a rational to establish collection centres given large number of dispersedly located smallscale farmers. The factory also has no plan to establish such centres but would encourage farmers to directly supply at the factory's gate or through cooperatives than through traders.

Proposition 2: The longer the horizontal structure of the value chain, the weaker the chain's integration.

In the view of Lambert and Cooper (2000), vertical VCS refers to the number of members within each tier of the value chain. A chain might have a narrow vertical VCS with few members or a wide vertical VCS with many members in the same tier. The authors indicate that value chains with wide vertical VCS cannot easily be integrated end-to-end. Members of such value chains usually limit their scope of integration only to their immediate suppliers and customers and leave the tasks of integration with distant members to the immediate suppliers and customers. The engagement of million farmers in malt barley the production and hundreds of traders and cooperatives in collection form too wide vertical VCS at the 
upstream tiers of the MBVC. On the other hand, the fact that a single malt factory operates in the mid-stream of the chain forms too narrow vertical structure.

A to the manager of Supply Chain Department of Heineken NV and a coordinator of the MBVC improvement project of the Self Help International, farmers' expressed about the dire needs for improved seeds and better market for malt barley which cannot be met through isolated efforts of value chain members, rather through strong integration of the entire chain. With that conviction, Heineken NN has already started with some preliminary initiatives that would improve MBVC integration.

The project called Community Revenue Enhancement through Agricultural Technology Extension (CREATE) funded by the Dutch Ministry of Foreign Affairs and the European Cooperative for Rural Development (EUCORD) is one of Heineken's initiatives to improve malt barley production, productivity and distribution in collaboration with other local partners such as Ethiopian Institute of Agricultural Research (EIAR) and Agricultural Transformation Agency (ATA). To this end, Heineken facilitated field trials of eight high yielding malt barley varieties brought from Europe at multiple sites in Ethiopia. Of the eight varieties, Traveler and Grace have performed well and received approval from the National Variety Releasing Committee (NVRC) for multiplication and distribution to farmers for wider production.

However, the engagement of too many but small-scale farmers in the malt barley production has formed a wide tier, which makes transactions execution somehow difficult given the weak cooperatives and opportunistic traders operating in the chain. Past studies have also reflected the same view that transactions execution is difficult with wider chain tiers (Lambert and Cooper, 2000).

Proposition 3: The wider the vertical structure of the value chain, the weaker the chain's integration.

The flow of information between members determines the level VCI (Mungandi Et al., 2012). The flow is said to be effective and efficient when information with right quantity and quality is shared between value chain members at the lowest possible costs (Raynolds Et al., 2009). But MBVC members, mostly famers at the upstream tier, have not yet understood the value of information as such. When farmers were asked about other members participating in the chain most of them do not know which members participate in distant tiers. Currently, farmers obtain more information from Development Agents (DAs) who are junior 
agriculturalists than from their chain partners. The malt factory frequently organizes training programs for model farmers on latest and best agricultural practices and technologies, and market linkages with the intention that these farmers would share the knowledge gained to other farmers. But knowledge sharing among farmers is a rare practice. In the view of the managers of the ESE, interactions between the two parties are not only less frequent, but also counterproductive. The factory's managers do not agree with the opinion of the enterprise's managers. In their view, ESE gives less emphasis to the multiplication and distribution of seeds of improved malt varieties compared to wheat. Otherwise, the malt factory works towards improving the malt barley quality through various innervations. Moreover, the enterprise lacks information on the efforts made by the factory. Obviously, information asymmetry hinders VCI.

Proposition 4: The poorer the flow of information along the value chain, the weaker the chain's integration.

As mentioned earlier, making choice among governance mechanisms is challenging to value members (Gellynck and Molnár, 2009). The horizontal and vertical structures of the value chain determine the magnitude of such challenges (Lambert and Cooper, 2000). The fit between transaction governance and transaction circumstances such as members involved, level of trust, and distribution of power improves VCI. Stringent transaction governance frustrates value chain members and pressurizes them to leave than to encourage their active participation (Dolan and Humphrey, 2000). Past studies highlights that the level of trust is a key governance mechanism that encourages value chain members to integrate their chain to avoid transactional risks (Mungandi Et al., 2012). When trust level is low, very stringent and costly quality monitoring measures are designed to control actions of other chain members (Kwon and Suh, 2004). In the view of interviewed farmers, for instance, the trust level between farmers and traders is very low. Similar finding was reported by Kambewa (2007) in her study on the Nile Perch value chain in which case traders collude to keep prices low. In the view of interviewed AMF's managers, traders' malfeasances has caused hostile working relationships which in turn reduced VCP outcomes.

By the virtue of low level of trust on traders, the malt factory undertakes strict quality control. Quality verification at the factory takes long time and entails higher costs. Traders have not option than to comply with quality control procedures set by the malt factory which is a monopsony. The traders are dissatisfied with unfriendly treatment of the malt factory. In 
traders' view, the malt factory is irrational in blaming all traders for the act of opportunism though there are still traders committed to ethical standards.

In the developed parts of the world, contact is another instrument widely used to facilitate transaction execution in agro-food chains (Mungandi Et al., 2012). In the view of the authors, contract somehow solves most of the problems of small-scale farmers such as lack of access to new technologies, inputs and markets, and price volatility. The authors explain the benefits that contract offers to large agro-food companies by enabling them control the delivery of the required inputs. During the 2012 planting season, Heineken NV started contract farming with 4,500 farmers through it CREATE project and distributed seeds of two newly tested varieties, Traveler and Grace, and good results were obtained. The use of these varieties have doubled productivity and shown positive sign to strengthen VCI. In the view of the project coordinator, these seeds were distributed to farmers through existing cooperatives after revitalization, and or newly organized cooperatives, and or model farmers as it is easier to deal with these entities than with individual farmers. The ESE is a pioneer to start contract farming few years ago and promising results were obtained. Meta brewery has also started contract farming with about 10,000 farmers last year through viable cooperatives with the target of reaching 50,000 farmers by 2017 if the pilot project yields good results.

Even though spot market is a widely used mode of transaction governance in developing countries (Vieira and Traill, 2008) its use in a pure form across the entire value chain is unlikely (Mikkola, 2008). Different forms of transaction governance are practiced at different links or mix of multiple forms could be used at some interfaces.

Proposition 5: The less effective the governance mechanism at various interfaces in the value chain, the weaker the chain's integration.

\section{Value chain integration}

In this study, VCI is conceptualized in terms of collaboration among members, coordination of activities across the value chain, commitments towards long-term relationships and readiness to make joint decisions. Though production managers of breweries and their counterparts in the malt factory meet regularly to discuss how to improve chain's integration and performance, significant results were not obtained. Since recently, meteoric opportunities were opened up, uniquely for farmers following the entrance of multinational breweries. Prior to their entry, local breweries failed to recognize the strategic importance of local sourcing to 
strengthen VCI and raise VCP. Moreover, top managers of breweries by then were not experts of value chain management (Slone Et al., 2007).

As pointed out earlier, members' readiness to make joint decisions is one aspect of VCI (Min Et al., 2005). In the view of interviewed farmers, farmers do planning together with cooperatives. The Agricultural Growth Strategy of Ethiopia requires farmers to prepare annual plans with the help DAs to properly manage own farming business. These plans are shared with cooperatives for better alignment of activities. But, farmers and traders neither plan together nor share information on their plans. The malt factory does not involve other members in its planning and decision making process. Few years back, the malt factory established a research fund to which breweries also contribute to support the joint Malt Barley Seeds Development Research Project at Kulumsa Agricultural Research Center (KARC). The project could not deliver expected results due to high mobility of researchers and lack of proper monitoring.

In the view of our key informants, collaboration among MBVC members and other stakeholders such as EIAR, ATA, agricultural research centers and seed enterprises on seed development is very poor irrespective of low productivity and poor quality of malt barley in the study area due to the use of outdated seeds. Most interviewed farmers could not understand the influence of malt barley quality on the quality of beer. As members in the upstream tier of the chain, farmers are expected to know the needs of other members so as to enhance the integration and performance of the chain.

In the view of the Head of the Agribusiness Department at Meta-Diageo, the introduction of improved seeds alone can enhance the quantity and quality of malt barley production. The manager further hinted that there is high level of farmers' frustration with current very low average productivity of 2 tons per hectare with poor quality. The use of improved seeds alone can double the productivity of malt barley. If the required volume and quality of malt are locally produced, breweries are relieved from the hassles that malt importation involves.

In the MBVC, cooperatives are expected to catalyze the flows of information, materials, and technologies. But most cooperatives could not even negotiate with AMF on terms of sales leave alone to fulfill the higher expectations of farmers. Past studies, as well, indicate the same scenario whereby value chain members switch to other products when existing products do not pay off (Slone Et al., 2007). Cooperative organizations in the study area are weak to provide the required supports to farmers mainly due to the following reasons. Firstly, farmers 
have bitter memories of bad legacies that cooperatives left in the past. Secondly, cooperatives are managed by an elect member for his/her behavioral qualities than managerial skills, as combination is difficult to find in rural setting. Thirdly, cooperatives managers are not incentivized for serving. Fourthly, stiff competition from persuasive and flexible traders. Lastly, poor support provided by District Cooperative Promotion Offices.

Even though breweries have the capacity to integrate with farmers through the malt factory, they rather pay more attention to the demand sides. They invest immense amount of their resources in promotion and distribution activities while these activities can be outsourced. The marketing divisions of breweries are well-organized than their procurement divisions. Breweries left the supply sides of the value chain to their suppliers. However, the concept of VCI has given considerable weight since the entrance of large multinational breweries.

Proposition 6: The weaker the integration of the value chain, the lower the chain's performance.

As explained earlier, product quality, flexibility, responsiveness and efficiency are used to measure VCP in most past studies (Molnar, 2010). Performance measurement parameters and methods should be standardized across value chains to achieve stronger VCI and higher VCP outcomes (Simatupang and Sridharan, 2008). In the MBVC, farmers measure performances from the point of views of goal achievement. However, majority of interviewed farmers are unhappy about the their achievements in terms of performance goals. Farmers do also measure performance in terms of product quality. In the view of the farmers, quality is the measure of grain moisture and purity, color and cleanness.. Responsiveness and flexibility are less used by farmers to measure performance. Lack of improved seeds and other agricultural inputs, non-responsive price to quality, absence of loans, information asymmetry, and low level of trust between value chain members are the major factors that constrain farmers' performance.

On the other hand, cooperatives staff measure performance in terms of their success in linking farmers to the downstream large agro-food processors to create sustainable and attractive market of malt barley. Cooperatives also measure their performance in terms of meeting the needs of farmers for agricultural inputs. The aggregate supply to AMF through cooperatives is less than $5 \%$ of the total factory's local sourcing which indicates poor performance of cooperatives. The main causes for these are lack of flexibility of cooperatives to adjust prices in tandem with traders' prices, low level of farmers' participation due to low 
level of trust, limited capacity and working capital, poor managerial skills, and more concentration on input supply than malt barley marketing. The malt barley supplied through cooperatives are always of lower quality grades not because of opportunism as it is a case for traders but due to the inability of cooperative staff to differentiate malt barley varieties and qualities.

Traders measure performance in terms of inventory turnover as they ration limited working capital among various agricultural crops. For traders, efficiency is the most critical performance indicator since they work under capital rationing. Moreover, traders wait longer to collect their receivables from malt barley sales on credit basis as the malt factory delays payment for couple of months which has a negative influence on their performance. Some traders also measure performance in terms of malt barley quality grades, in which case first grade implies best performance while last grade represents the least.

According to the malt factory's production manager, performance is measured in terms of the volume of malt produced and the quality standards adopted from European Brewery Convention (EBC). Malt quality is determined by the amount of extractable wort. Accordingly, local malt is with low level of wort mainly due to poor quality of local malt barley in terms of grain size, moisture level, protein content, and germination capacity. Since the malt factory uses world-class malting technologies, the poor quality of malt can be mainly attributed to the use of poor quality malt barley supplied from local sources.

Even though all breweries are ISO certified for meeting the required performance standards, as indicated by respective production managers, still there is a long way to go. These breweries could not achieve as much as they should due to less quantity and poor quality of malt supplied from locally. Moreover, the malt is not available for just- on-time delivery due to weak coordination of activities as information exchange on production and distribution activities are very poor.

\section{Concluding comments}

This study paid a particular attention to value chain members' geographic dispersion, their horizontal and vertical arrangements within and across tiers, the governance of transactions, the flows of information among members and how all these factors affect the performance of the MBVC by influencing its integration. We explored how farmers, cooperatives, traders, the malt factory and breweries are interconnected and how these interactions are governed at various interfaces and associated with MBVC integration and then performance. The study 
revealed that MBVC members are dispersedly located over wider geographic areas, widervertical and longer-horizontal arrangements of these members within and across tiers, and the use of ineffective transaction governance mechanisms which contributed to weak integration and low performance of the MBVC though further investigation is required for better validation.

The study identified variations among MBVC members in terms of the quantity and quality of information generated and shared with other chain members. The upstream members of the MBVC have less information and the situation improves as one moves down along the chain. The variation in the level of information generated mainly results from members' variations in terms of capacity to generate information and access to information sources. For instance, farmers and cooperatives have less information than any other members due to limited information generating capacity and less access to information sources. Breweries and the malt factory are less willing to share information on product specifications to upstream members though it is quite useful for decision making.

The study identified several fragmentations in the MBVC structure that have contributed to the weak integration and low performance of the chain. The quality of malt barley produced is far below the required standard. Cooperative organizations are poorly structured to make bulk collection of malt barley. Traders are extensively engaged in the adulteration of good quality malt barley with poor ones to serve their egoistic profit desires. The level of collaboration among members on malt barley seeds development is minimal. This study has provided a conceptual framework that can be replicated in other similar studies with reference to agricultural value chains in developing countries for better generalizability of the findings. This study also provides important managerial insights concerning the structure, integration and performance of the MBVC. The disperse geographic locations of members, poor flows of information along the value chain, the use of ineffective transaction governance mechanism, weak cooperatives organizations, ineffective agricultural research system and absence of common platform for members dialoging are some of the factors that contribute to weak integration and low performance of the MBVC that its members and stakeholders should work on to improve and sustain chain's integration and performance.

\section{Acknowledgment}

The study was funded by the Netherlands Organization for International Cooperation in Higher Education (Nuffic) through the NicheETH019, a consortium project of four Ethiopian 
universities in collaboration with partner universities in the Netherlands and Belgium, to support the commercialization processes in the agriculture sector in Ethiopia. The second author acknowledges the financial support of the Hungarian Scientific Research Fund (OTKA, PD 116226) 'Supply chain and network performance and relationships in the agribusiness sector'.

\section{References}

Awad, H., and M. Nassar. 2010. Supply chain integration: Definition and challenges. Paper read at International Multi-conference of Engineers and Computer Scientists (IMECS2010), March 17-19, 2010, at Hong Kong.

Bastl, M., M. Johnson, H. Lightfoot, and S. Evans. (2012). Buyer-supplier relationships in a servitized environment: an examination with Cannon and Perreault's framework. International journal of operations \& Production Management 32(6): 650-675

Baxter, P., and S. Jack. (2008). Qualitative case study methodology: Study design and implementation for novice researchers. The qualitative report 13(4): 544-559

Bijman, J., B. M. Kamphuis, R. C. Wiersinga, M. G. Danse, X. Y. Zhang, and D. Hu. 2010. Linking small-scale farmers to modern retail chains: the case of China-SPAR. In Towards effective food chains-Models and applications: Wageningen Academic Publishers.

Bitzer, V. (2012). Partnering for change in chains: The capacity of partnerships to promote sustainable change in global agrifood chains. Managing wicked problems in agribusiness: 13

Brüntrup, M. 1997. Agricultural price policy and its impact on production, income, employment and the adoption of innovations: a farming systems based analysis of cotton policy in northern Benin: Peter Lang Verlag.

Cao, M., and Q. Zhang. (2010). Supply chain collaborative advantage: a firm's perspective, . International Journal of Production Economics 128: 358-367

Dolan, C., and J. Humphrey. (2000). Governance and trade in fresh vegetables: the impact of UK supermarkets on the African horticulture industry. Journal of development studies 37(2): 147-176

Ellram, L. (1996). The use of case study method in logistics research. Journal of Business Logistics 17(2): 93-138

Gellynck, X., and A. Molnár. (2009). Chain governance structures: the European traditional food sector. British Food Journal 111(8): 762-775

Gellynck, X., A. Molnár, and L. Aramyan. (2008). Supply chain performance measurement: the case of the traditional food sector in the EU. Journal on Chain and Network Science 8(1): 47-58

Ghosh, A., and J. Fedorowicz. (2008). The role of trust in supply chain governance. Business Process Management Journal 14(4): 453-470

Ho, K., F. Au, and E. Newton. (2002). Empirical research on supply chain management: a critical review and recommendations. International Journal of Production Research 40: $4415-4430$

Kambewa, E. 2007. Balancing the poeple, profit and planet dimensions in international marketing channels: A study on coordinating mechanisms in the Nile perch channel from Lake Victoria, Wageningen University, the Netherlands, Wageningen Academic Publisher. 
Kwon, I.-W. G., and T. Suh. (2004). Factors affecting the level of trust and commitment in supply chain relationships. Journal of Supply Chain Management 40(1): 4-14

Lambert, D. M., and M. C. Cooper. (2000). Issues in supply chain management. Industrial Marketing Management 29(1): 65-83

Legesse, G., S. Debebe, and T. Alemu. 2007. Assessing the uncomparative advantage of malt barley production in Ethiopia: application of policy analysis matrix. Paper read at African Crop Science Conference

Mikkola, M. (2008). Coordinative structures and development of food supply chains. British Food Journal 110(2): 189-205

Min, S., A. S. Roath, P. J. Daugherty, S. E. Genchev, H. Chen, A. D. Arndt, and R. G. Richey. (2005). Supply chain collaboration: what's happening? International Journal of Logistics Management 16(2): 237-256

Molnar, A. 2010. Supply chain performance and relationships: the European traditional food sector, Agricultural Economics, Agri-food Marketing and Chain Management Division, Ghent University, Ghent, Belgium.

Mungandi, S., D. Conforte, and N. M. Shadbolt. (2012). Integration of smallholders in modern agri-food chains: lessons from the KASCOL model in Zambia. International Food and Agribusiness Management Review 15(3)

Pagell, M. (2004). Understand the factors that enable and inhibit the operation, purchasing and logistics. Journal of Operations Management 22: 459-487

Raynolds, N., C. Fischer, and M. Hartmann. (2009). Determinants of sustainble business relationships in selected German agri-food chains. British Food Journal 111(6): 776793

Romano, P. (2003). Co-ordination and integration mechanisms to manage logistics processes across supply networks. Journal of Purchasing and Supply Management 9(3): 119134

Simatupang, T., and R. Sridharan. (2008). Design for supply chain collaboration. Business Management Process Journal 14(3): 401-418

Slone, R. E., J. T. Mentzer, and J. P. Dittmann. (2007). Are you the weakest link in your company's supply chain? Harvard Business Review 85(9): 116

Steen, M., and W. Maijers. (2014). Inclusiveness of the Small-Holder Farmer Key Success Factors for Ethiopian Agribusiness Development. International Food and Agribusiness Management Review 17(B)

Stock, G. N., N. P. Greis, and J. D. Kasarda. (2000). Enterprise logistics and supply chain structure: the role of fit. Journal of Operations Management 18(5): 531-547

Vandeplas, A., B. Minten, and J. Swinnen. (2013). Multinationals vs. cooperatives: The income and efficiency effects of supply chain governance in India. Journal of Agricultural Economics 64(1): 217-244

Vieira, L. M., and W. B. Traill. (2008). Trust and governance of global value chains: the case of a Brazilian beef processor. British Food Journal 110(4/5): 460-473

Villena, V., L. Gomez-Mejia, and E. Revali. (2009). The decision of supply chain exectives to support or impede supply chain integration: A multidisplininary behavioral agency perspective. Journal of Decision Science 40(4): 635-665

Wu, W.-Y., C.-Y. Chiag, Y.-J. Wu, and H.-J. Tu. (2004). The influencing factors of commitment and business integration on supply chain management. Industrial Management \& Data Systems 104(4): 322-333 


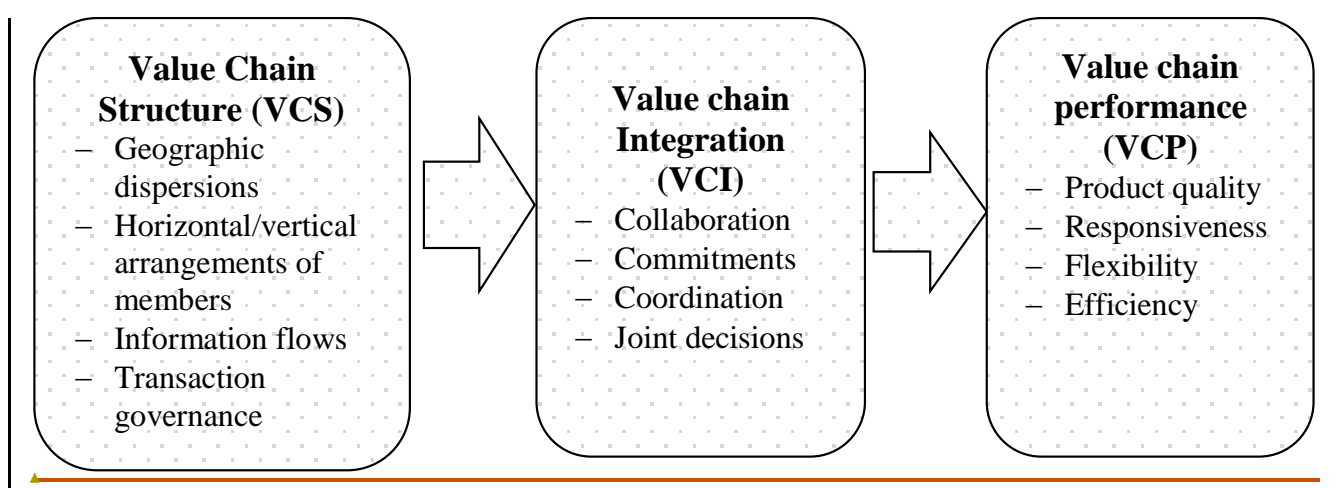

Formázott: Betűtípus: Félkövér

Fig 1: Conceptual framework that associates VCS, VCI and VCP.

Source: Own formulation based on (Ghosh and Fedorowicz, 2008; Molnar, 2010; Pagell, 2004; Stock Et al., 2000)

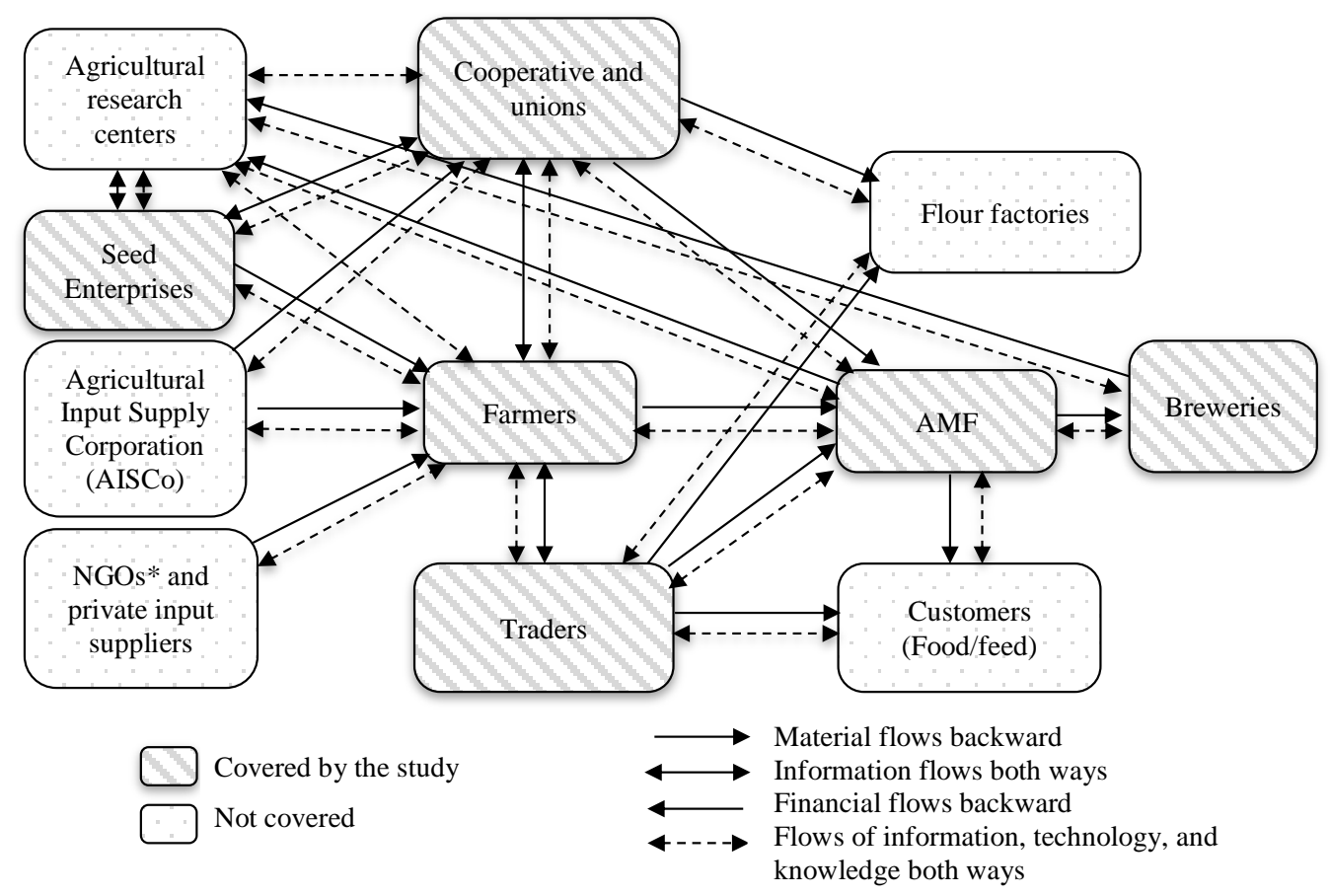

| * None governmental organizations working on malt-barleymalt barley improvements Source: Own construction based on our empirical data

Fig 32: $M B V C \mid \underline{M} m a p$ of the Malt barley value chain in Ethiopia

Megjegyzés [JK1]: Caption needs to be more explicit

Table 1.: Land use, maMalt barleylt barley and malt productionproduction and procurement and malt production in the study area over the period 2009-2013.

Megjegyzés [JK2]: Caption needs to be more explcit

\begin{tabular}{|c|c|c|}
\hline \multirow{2}{*}{ Year } & Case Districts & Assela Malt Factory (AMF) \\
\hline & Land used for malt- Malt-barleyMalt & Malt- $\quad$ Malt \\
\hline
\end{tabular}




\begin{tabular}{|c|c|c|c|c|}
\hline & $\begin{array}{l}\text { barleymalt barley } \\
\text { (hectares) }\end{array}$ & $\begin{array}{l}\text { barley production } \\
\text { (tons) }\end{array}$ & $\begin{array}{l}\text { barleyMalt } \\
\text { barley } \\
\text { purchase } \\
\text { (tons) }\end{array}$ & $\begin{array}{l}\text { production } \\
\text { (tons) }\end{array}$ \\
\hline 2009 & 20,390 & 59,131 & $21,704.69$ & $16,819.60$ \\
\hline 2010 & 17,439 & 45,341 & $23,718.70$ & $11,526.30$ \\
\hline 2011 & 19,602 & 54,886 & $34,861.51$ & $22,595.05$ \\
\hline 2012 & 19,316 & 48,290 & $20,244.29$ & $25,727.73$ \\
\hline 2013 & 24,374 & 65,810 & $27,820.70$ & $20,724.30$ \\
\hline
\end{tabular}

Source: District offices of Agriculture and AMF 